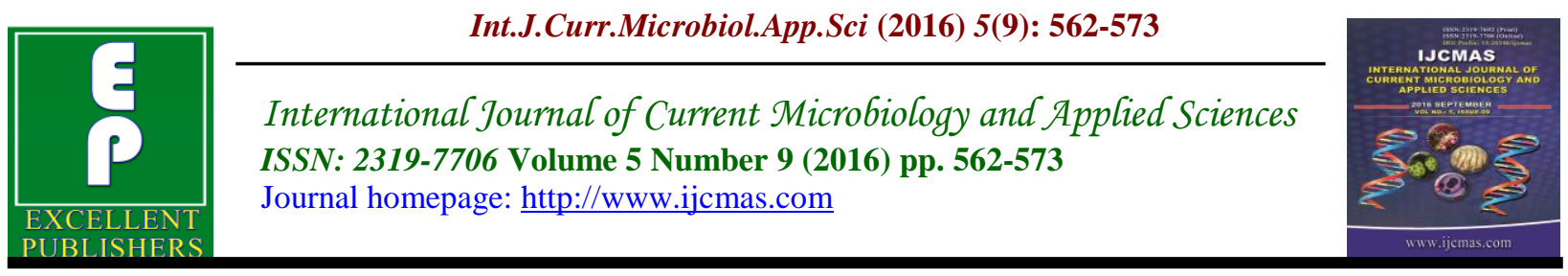

Original Research Article

http://dx.doi.org/10.20546/ijcmas.2016.509.063

\title{
Seroprevalence of Herpes Simplex Virus2 in Sexually Transmitted Diseases in a Tertiary Care Hospital in Visakhapatnam, India
}

\author{
Venkata Hemalatha Neeli, Perala Bala Murali Krishna*and Medidi Deborah Purushottam
}

\author{
Department of Microbiology, Andhra Medical College, Visakhapatnam, India \\ *Corresponding author
}

\section{Keywords}

Herpes simplex, virus type 2 , Sexually Transmitted Diseases, Subclinical shedding, Seroprevalence, Screening.

\section{Article Info}

Accepted:

20 August 2016

Available Online:

10 September 2016

\section{A B S T R A C T}

Herpes simplex virus type 2 (HSV2) infection is the primary cause of genital herpes and one of the most frequent sexually transmitted diseases world-wide. Subclinical shedding of HSV occurs in persons with a history of genital herpes and is instrumental in transmitting HSV infection. This study was carried out to find out the seroprevalence of HSV2 among sexually transmitted diseases patients, to examine the influence of certain factors associated with HSV2 infection and to evaluate the need for regular HSV2 seroprevalence surveys. Patients attending Sexually Transmitted Diseases (STD) out-patient department (OPD) with complaints of vesicles and ulcers over the genital region, either in their initial presentation or recurrence were examined for the presence of herpes virus infection by microscopy and serology. Majority of the STD patients with antibodies to HSV2 did not have history of genital herpes. This finding drives home the importance of screening in a community as the majority of persons infected with HSV2 infection is symptom-free and thus represent the major reservoir for HSV2 transmission.HSV2 seroprevalence is high among HIV seropositive individuals than among HIV seronegative individuals. HSV2 could thus be an important risk factor associated with HIV acquisition.

\section{Introduction}

'Venus' is the Goddess of love as per Greek mythology and that's the origin of the word 'Venereal Diseases'. The older terminology of 'venereal diseases' largely has been superseded in cast 50 years by, 'sexually transmitted diseases' (STDs) and more recently by sexually transmitted infections' (STIs). Both ulcerative and non-ulcerative STIs have emerged as a major public health problem in all populations and socioeconomic groups world-wide. Over 300 million new cases are reported annually and
$75 \%-85 \%$ of them are in developing countries. The incidence and spread of STIs are greatly influenced by numerous factors such as availability of multiple sexual partners, the presence of asymptomatic infection, the frequent movement of people within populations and increasing affluence (Bhushan Kumar et al., 2005).

The Herpes virus family contains several of the most important human viral pathogens. Clinically, the Herpes virus exhibits a 
spectrum of diseases. The outstanding property of herpes virus is their ability to establish life-long persistent infections in their hosts and to undergo periodic reactivation. Their frequent reactivation in the immunosuppressed patients causes serious health complications (Jawetz et al., 2013).

Herpes simplex virus type 2 (HSV2) infection is the primary cause of genital herpes and one of the most frequent sexually transmitted diseases world-wide (Anna Wald et al., 1997, 2004; David et al., 2004; Sgaier et al., 2011). Subclinical shedding of HSV occursin persons with a history of genital herpes and is instrumental in transmitting HSV infection to sexual partners and neonates (Anna Wald et al., 1995).

HSV2 prevalence is increasing worldwide, and has become a prominent public health issue over recent years. More than $80 \%$ of primary HSV2 infections are asymptomatic. Therefore the prevalence of the disease is best assessed by serological surveys. The prevalence of HSV2 antibodies is dependent on sexual activity, ranging from $0 \%$ in celibate adults to over $80 \%$ in commercial sex workers (David et al., 2004; Weatherall, 1996).

The main and objectives of this study to find out the seroprevalence of HSV2 among sexually transmitted diseases patients. To examine the influence of certain factors associated with HSV2 infection. And also to evaluate the need for regular HSV2 seroprevalence surveys.

\section{Materials and Methods}

The present cross sectional study was conducted at King George Hospital (KGH), a tertiary care hospital in Visakhapatnam over a period of seventeen months, i.e., from
February 2014 to June 2015. The study group included100 patients attending Sexually Transmitted Diseases (STD) outpatient department (OPD) with complaints of vesicles and ulcers over the genital region, either in their initial presentation or recurrence. Patients already on treatment with anti-viral agents were excluded from the study.

Their consent for participation in the study was obtained. Detailed history of each and every patient pertaining to the name, age, sex, address, education, occupation, income, socio-economic status, marital status, name and occupation of the spouse if married, multiple sexual partners (if any), whether belonging to any high risk group (such as CSWs, MSM, IV drug users, truck drivers), complaints and duration of symptoms, past history of genital herpes or a different STI, history of similar complaints of the partner was taken and examination findings were noted down. The diagnosis of herpes virus infection was made by microscopy and serology.

\section{Microscopy}

\section{Tzanck smear examination}

The vesicles were unroofed with a sterile needle.

Base of the lesions were scraped with sterile surgical blade.

The material thus obtained was smeared onto a clean glass slide.

The smears thus prepared were then fixed with gentle heat.

They were then stained with $1 \%$ aqueous solution of toluidine blue ' $\mathrm{O}$ ' for 15 seconds. 
The smears thus prepared were examined under oil immersion objective for multinucleated giant cells with faceted nuclei and homogenously stained 'ground glass' chromatin, the "Tzanck cells" (Figure 1).

\section{Serology}

\section{Collection of blood samples}

Using sterile disposable syringes, under strict aseptic conditions, about $5 \mathrm{ml}$ of blood was withdrawn by venipuncture.

Blood thus collected was then transferred into sterile blood collection tubes (vacutainer tubes) with clot activator.

The blood sample was centrifuged; serum was separated and transferred into sterile provials.

Serum thus obtained was preserved at -70 ${ }^{\circ} \mathrm{C}$.

All the samples were screened for HSV2 type specific IgM and $\operatorname{IgG}$ antibodies by ELISA [EUROIMMUN] and the results were noted.

\section{Test Procedure ofAnti-HSV-2 (gG2) ELISA (IgM and IgG)}

\section{Principle of the test}

The test, based on the principle of ELISAdetected the presence of human antibodies of IgMand IgGclass against the HSV-2 specific glycoprotein $\mathrm{G} 2$ in the serum respectively. The test kits (two in number, one for $\operatorname{IgM}$ and the other for IgG)(Figure 2)containedmicrotiter strips each with 8 break-off reagent wells coated with purified glycoprotein G2. In the first reaction step, diluted patient samples were incubated in the wells. In the case of positive samples, specific $\operatorname{IgM}$ and $\operatorname{IgG}$ antibodies bound to the antigens. To detect the bound antibodies, a second incubation was carried out using an enzyme-labelled anti-human IgM and IgG (enzyme conjugate), which was capable of catalyzing a colour reaction. The intensity of thecolour formed was proportional to the concentration of $\operatorname{IgM}$ and $\operatorname{IgG}$ antibodies against HSV-2 glycoprotein gG2.

Preparation of the reagents was done as per the manufacturer's instructions.

All reagents were brought to room temperature before use.

The coated wells were opened after tearing off the protective wrapping and after the microplate has reached the room temperature.

The calibrator and controls were mixed thoroughly before use.

The serum samples for analysis were diluted 1:101 with sample buffer.

The wash buffer was diluted 1: 10 with distilled water.

The enzyme conjugate was mixed thoroughly before use.

The bottle of chromogen/substrate solution was closed immediately after use as the contents are sensitive to light exposure.

\section{Sample incubation (Figure 3)}

$100 \mu \mathrm{l}$ each of the calibrator, positive and negative controls, and diluted patient samples sera were pipetted into the individual microplate wells and incubated for 30 minutes at room temperature. After incubation, the wells were emptied and 
subsequently washed 3 times using $300 \mu$ of working strength wash buffer per well for each wash. The wash buffer was left in each well for 30 to 60 seconds per washing cycle. The wells were then emptied. After washing, the microplate was thoroughly disposed of all liquid by tapping it on absorbent paper, with the openings facing downwards, to remove all residual wash buffers.

\section{Conjugate incubation (Figure 4)}

$100 \mu 1$ of enzyme conjugate (peroxidelabelled anti human $\operatorname{IgM}$ and $\operatorname{IgG}$ ) was pipetted into each of the microplate wells and incubated for 30 minutes at room temperature. After incubation, the wells were emptied and washed as described earlier.

Substrate incubation: $100 \mu \mathrm{l}$ of chromogen/substrate solution was pipetted intoeach of the microplate wells and incubated for 15 minutes at room temperature in the dark.

Stopping the reaction: $100 \mu \mathrm{l}$ of stop solution was pipetted into each of the microplate wells in the same order and at the same speed as the chromogen/substrate solution was introduced.

Photometric measurement: The color intensity was measured at a wavelength of $450 \mathrm{~nm}$ and a reference wavelength between $620 \mathrm{~nm}$ and $650 \mathrm{~nm}$ within 30 minutes of adding the stop solution (Figure 5 and Figure 6 show ELISA reader and ELISA washer respectively). A homogenous distribution of the solution was ensured prior to measuring by slightly shaking the microplate.

\section{Calculation of the results (Figure 7)}

Results were evaluated semi-quantitatively by calculating a ratio of the extinction value of the control or patient sample over the extinction value of calibrator and calibrator 2 for $\operatorname{IgM}$ and $\mathrm{IgG}$ respectively.

Ratio $=$

Extinction value of the control or patient sample Extinction value of calibrator/ calibrator 2

Results were interpreted as follows:

$\begin{array}{lll}\text { Ratio } & <0.8 & : \text { negative } \\ \text { Ratio } & \geq 0.8 \text { to }<1.1 & : \text { borderline } \\ \text { Ratio } & \geq 1.1 & : \text { positive }\end{array}$

Both positive and negative controls served as internal controls for the reliability of the test procedure.

\section{Results and Discussion}

Among the 100 patients included in the study, $72 \%$ were men and $28 \%$ were women. Seroprevalance of HSV2 and its relation to the Tzanck smear positivity is shown in Tables 1 and 2 respectively.

Majority of the cases, $42 \%$ that were HSV2 seropositive belonged to 31-40 years of agegroup (Diagram 1). In the study population, only $12 \%$ individuals with antibodies to HSV2 gave history of symptoms suggestive of genital herpes (Diagram 2).Recurrence of the symptoms wasreported by $35 \%$ of the seropositive individuals (Diagram3).

Sixty-three percent of seropositives were married and $83 \%$ belonged to low socioeconomic group (Diagram 4). 53\% of them had multiple sexual partners (Diagram 5). $35 \%$ of seropsitives were drivers by occupation (Diagram 6). Majority of them, $89 \%$ were notusing any barrier methods (Diagram 7). Men who have Sex with Men (MSM) were $3 \%$ and the remaining were heterosexuals and all were sexually active. Association of HSV2 with HIV infection was also observed in $69 \%$ (Table 3 ). 
In the present study, a higher seroprevalence of HSV2 was observed among the high risk groups compared to the general population.
Similar findings were observed by Steben and Sacks (1997); Nahmias et al., (1990) and Santos et al., (1996).

Table.1 HSV2 IgM and IgGseroprevalence ( $\mathrm{n}=100)$

\begin{tabular}{|c|c|c|}
\hline $\begin{array}{c}\text { HSV2 } \\
\text { Seroprevalence }\end{array}$ & IgM & IgG \\
\hline Positive & 9 & 28 \\
\hline Borderline & 1 & 8 \\
\hline Negative & 90 & 64 \\
\hline Total & 100 & 100 \\
\hline
\end{tabular}

Table.2 Tzanck smear positivity $(\mathrm{n}=100)$ in relation to HSV2 seroprevalance

\begin{tabular}{|c|c|c|c|}
\hline Tzanck smear & Study group & $\begin{array}{c}\text { In HSV2 IgM } \\
\text { antibody } \\
\text { Positive }\end{array}$ & $\begin{array}{c}\text { In HSV2 IgG } \\
\text { antibody } \\
\text { Positive }\end{array}$ \\
\hline Positive & 13 & 2 & 11 \\
\hline Negative & 87 & 7 & 17 \\
\hline Total & 100 & 9 & 28 \\
\hline
\end{tabular}

Table.3 Association of HSV2 with HIV infection ( $\mathrm{n}=100)$

\begin{tabular}{|c|c|c|c|c|c|c|c|}
\hline \multirow{2}{*}{$\begin{array}{c}\text { Association } \\
\text { with HIV } \\
\text { infection }\end{array}$} & \multirow{3}{*}{ Total } & \multicolumn{3}{|c|}{ HSV2 IgM antibody } & \multicolumn{3}{c|}{ HSV2 IgG antibody } \\
\cline { 3 - 8 } & & Positive & Borderline & Negative & Positive & Borderline & Negative \\
\hline Reactive & 13 & 0 & 0 & 13 & 2 & 7 & 4 \\
\hline Non-reactive & 87 & 9 & 1 & 77 & 26 & 1 & 60 \\
\hline
\end{tabular}

Fig.1 Tzanck smear showing multi-nucleated giant cells

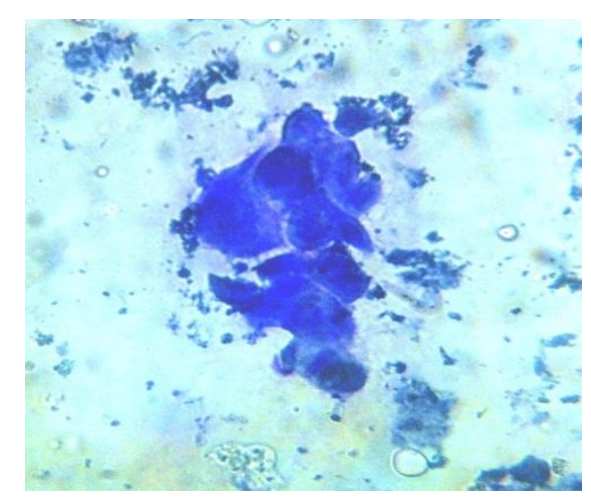


Fig.2 Contents of HSV2 IgM and IgG ELISA kits

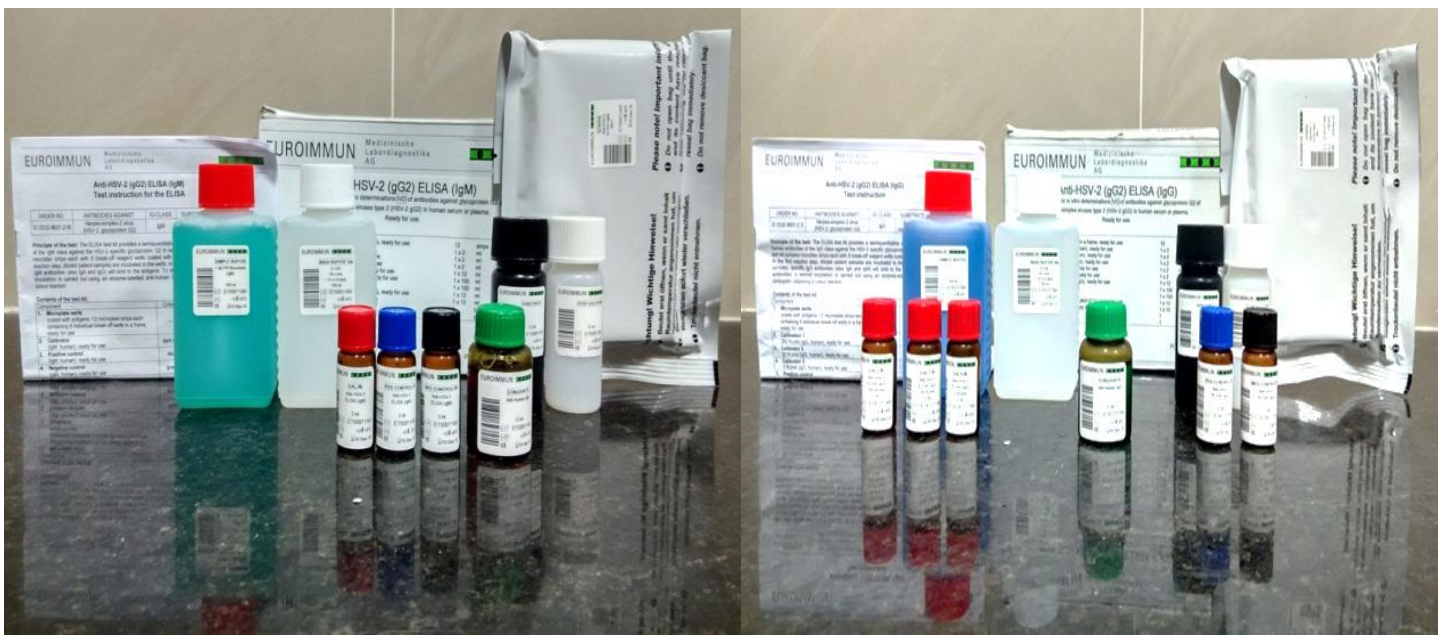

Fig.3 HSV2 IgM and IgG ELISA - Diluted sera
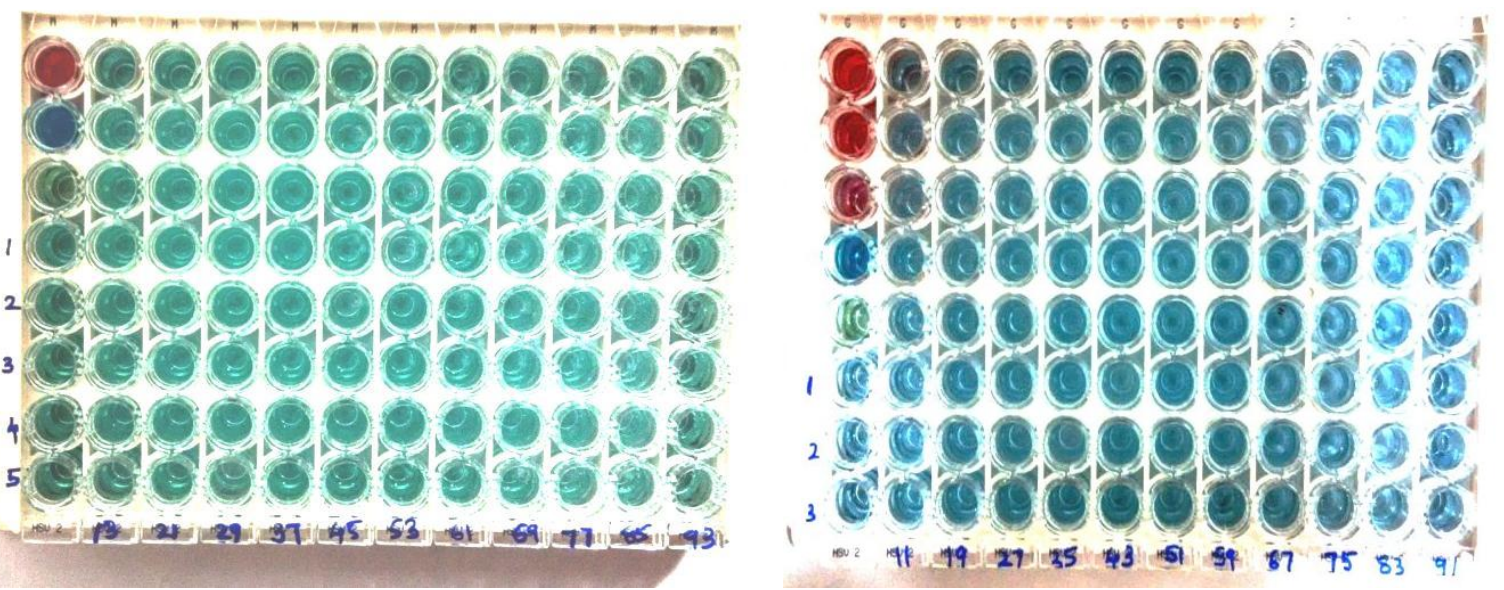

Fig.4 HSV2 IgM and IgG ELISA - Conjugate incubation
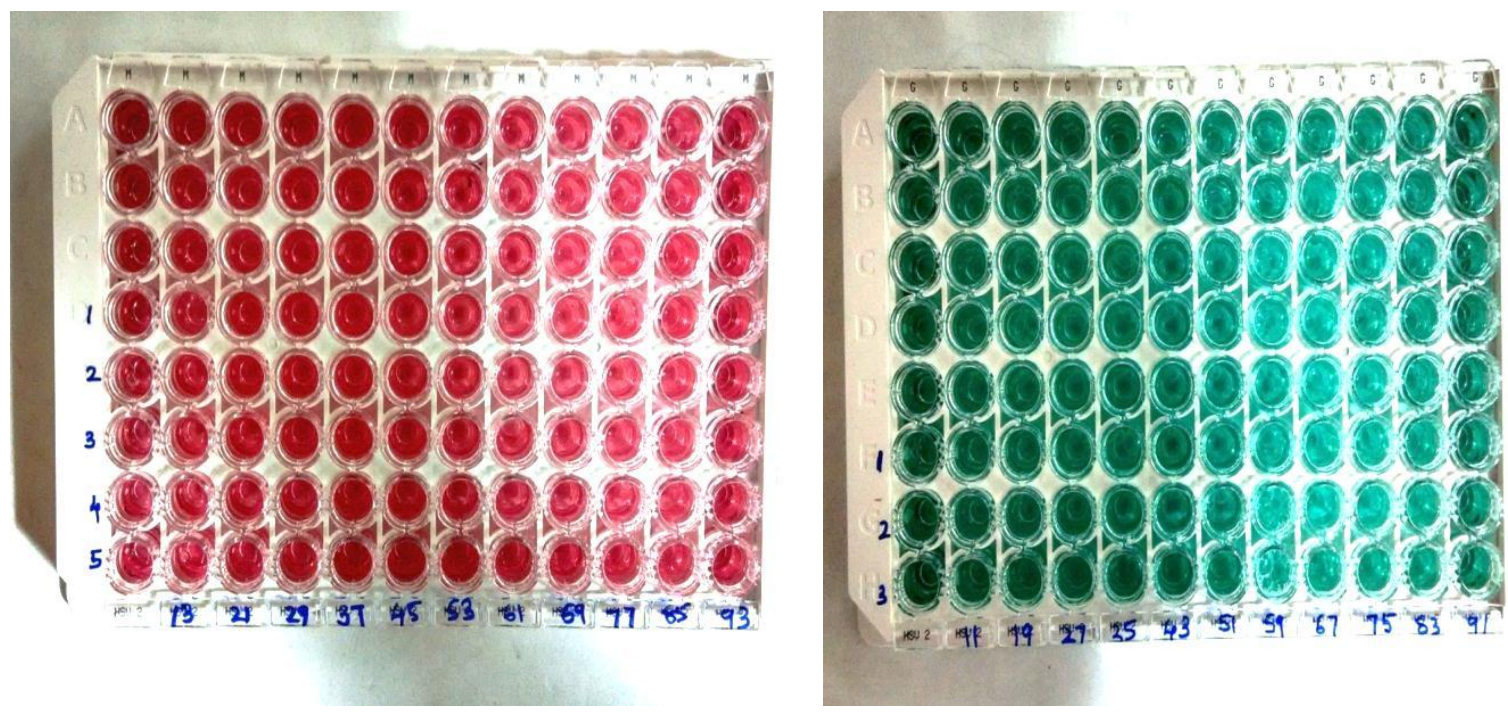
Fig.5 ELISA Reader

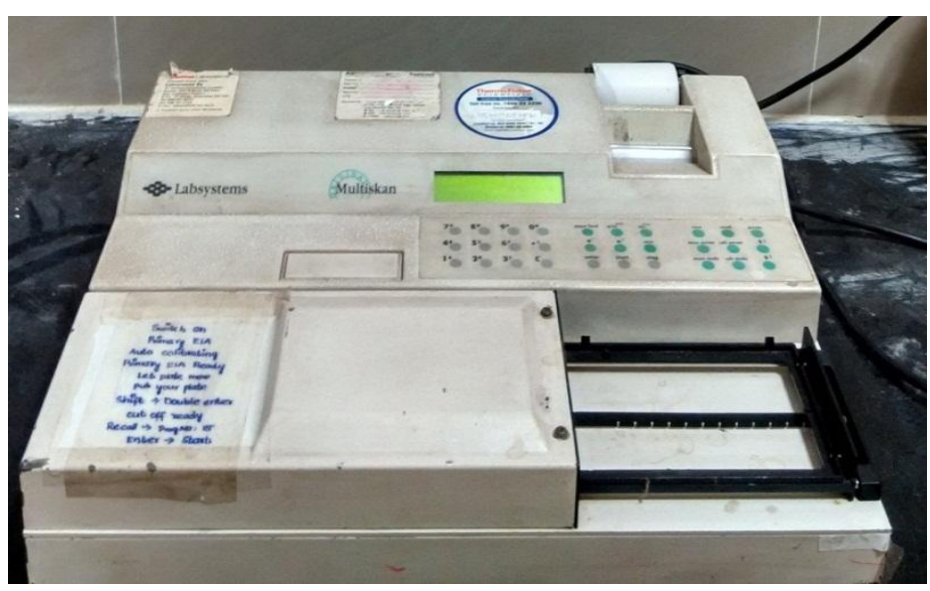

Fig.6 ELISA Washer

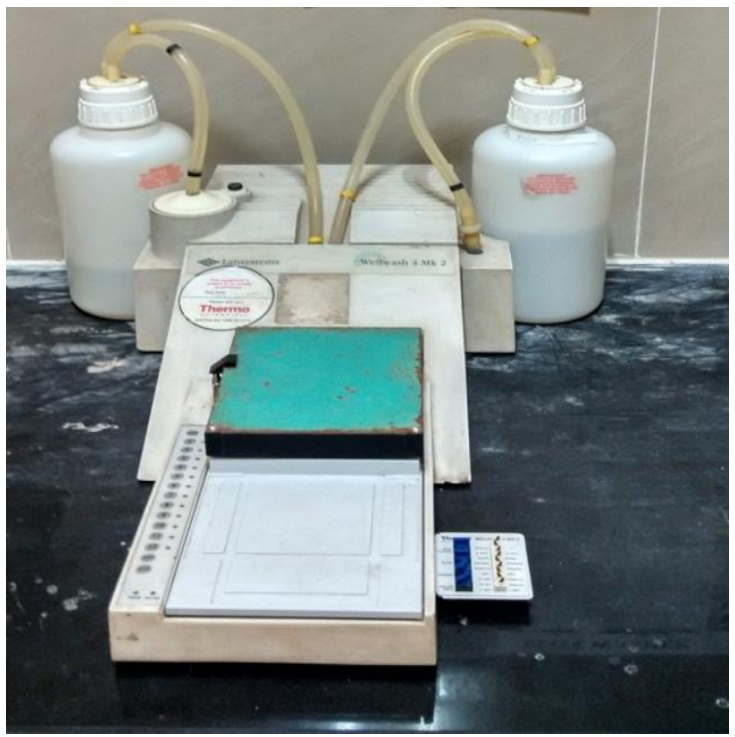

Fig.7 HSV2 IgM and IgGELISA - Results

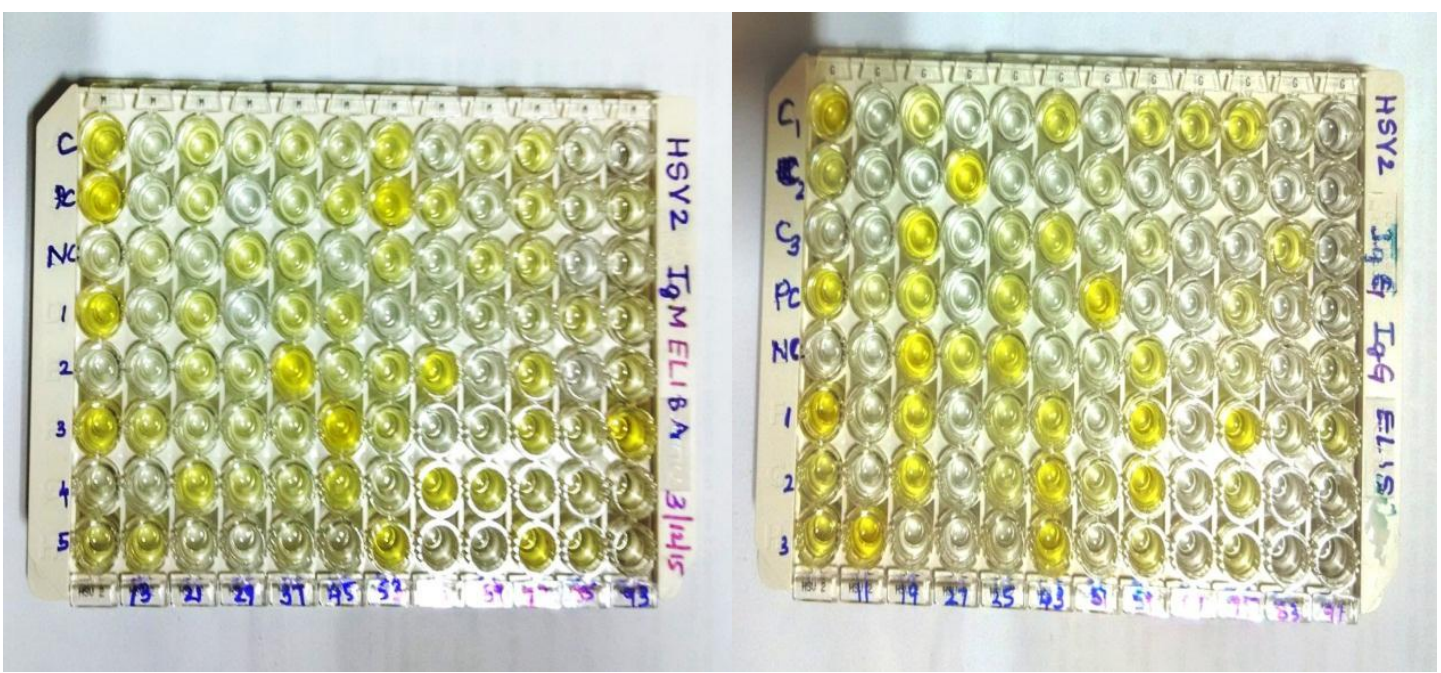




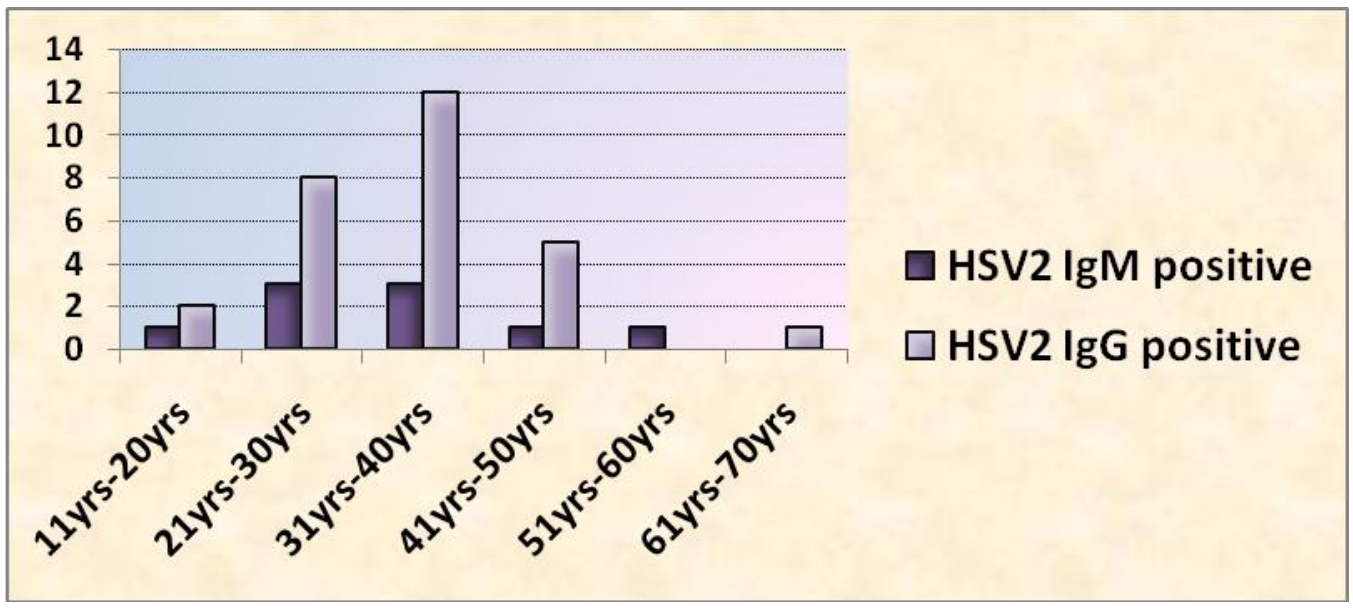

Diagram 1: Bar diagram showing HSV2 seroprevalence in relation to age

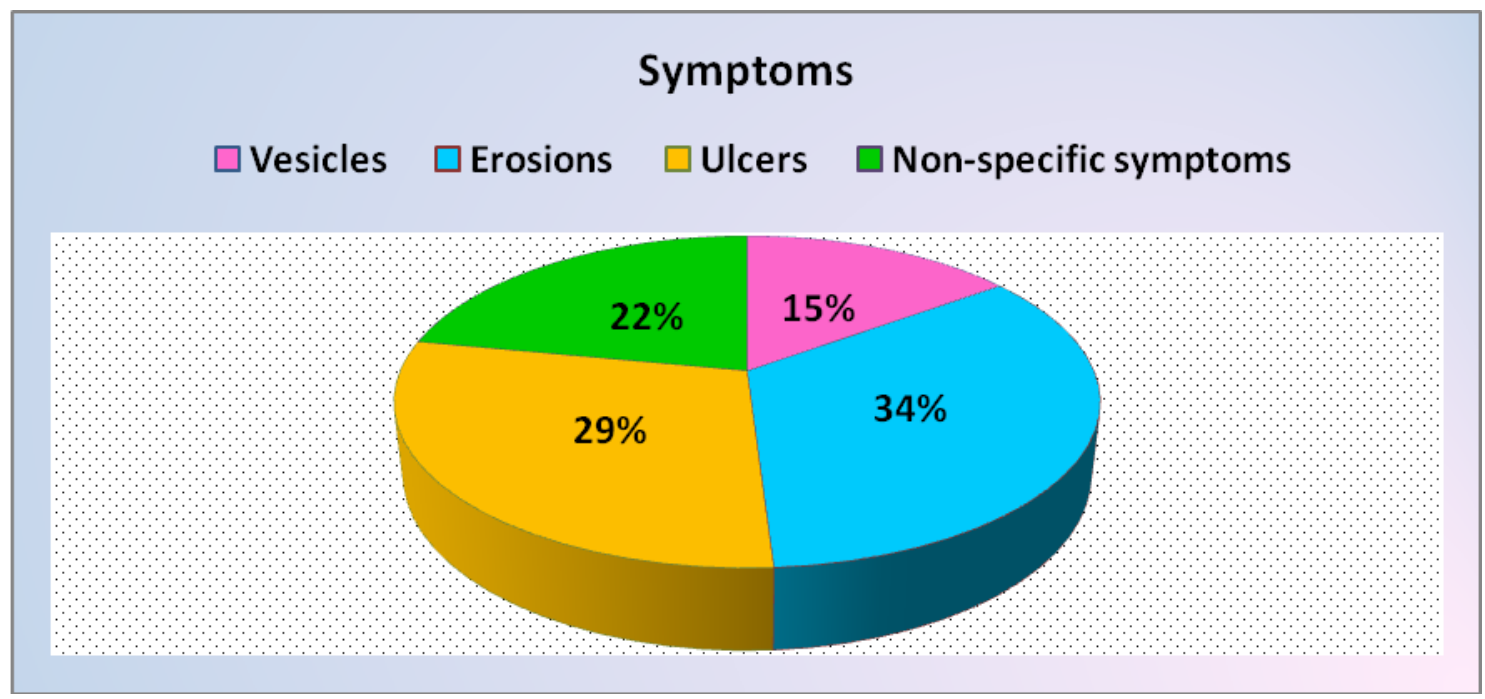

Diagram 2: Pie diagram showing symptom-wise distribution of cases

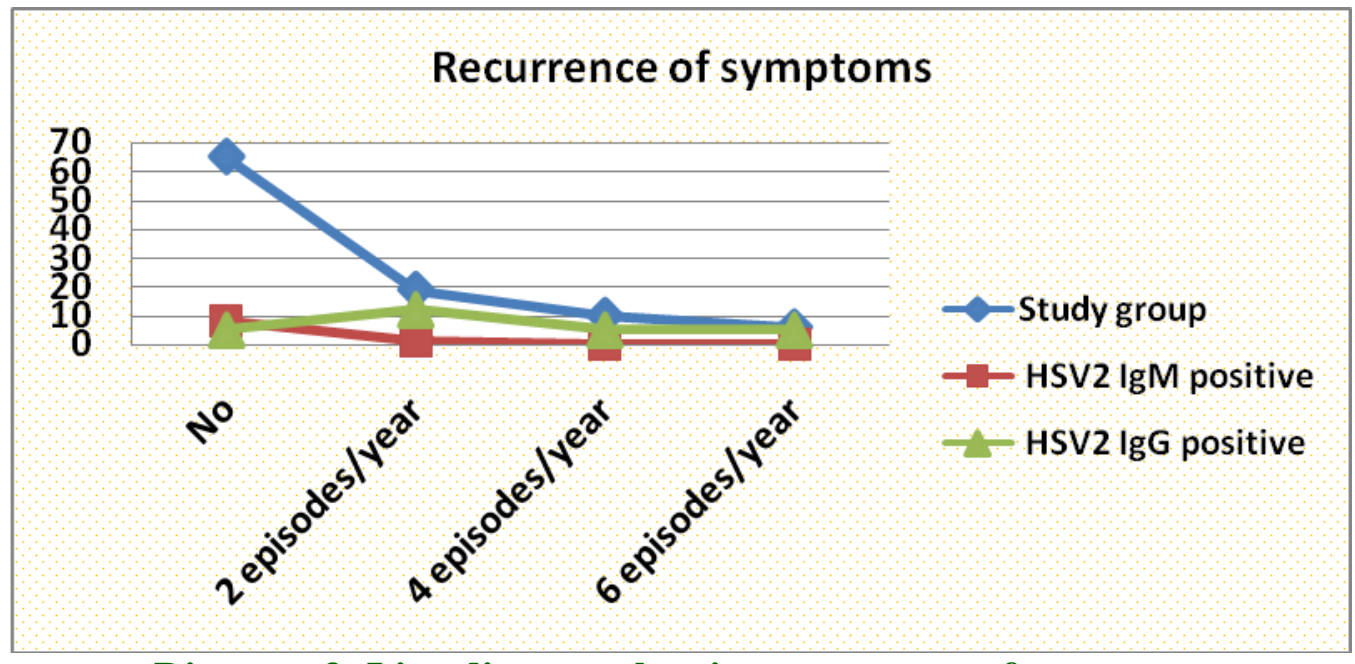

Diagram 3: Line diagram showing recurrence of symptoms 


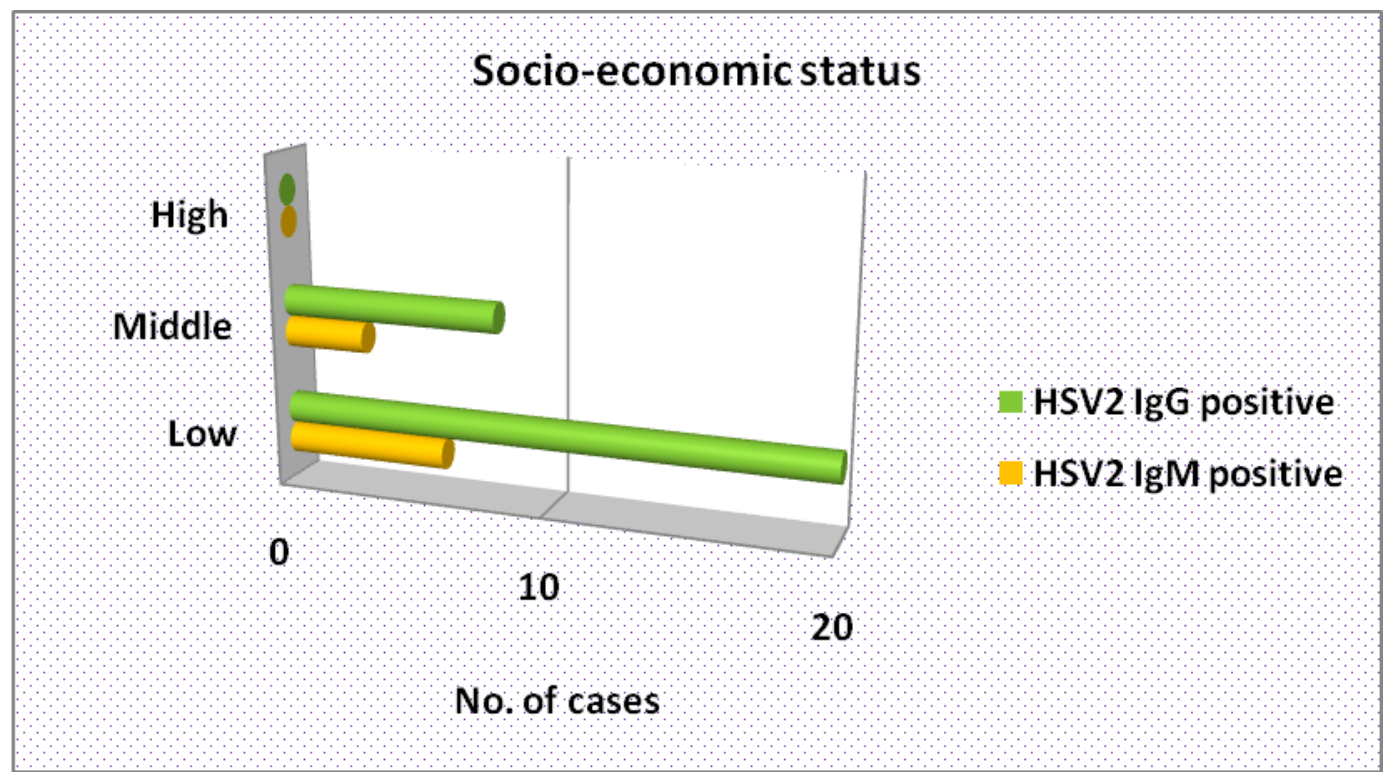

Diagram 4: Bar diagram showing HSV2 seroprevalence in relation to socio-economic status

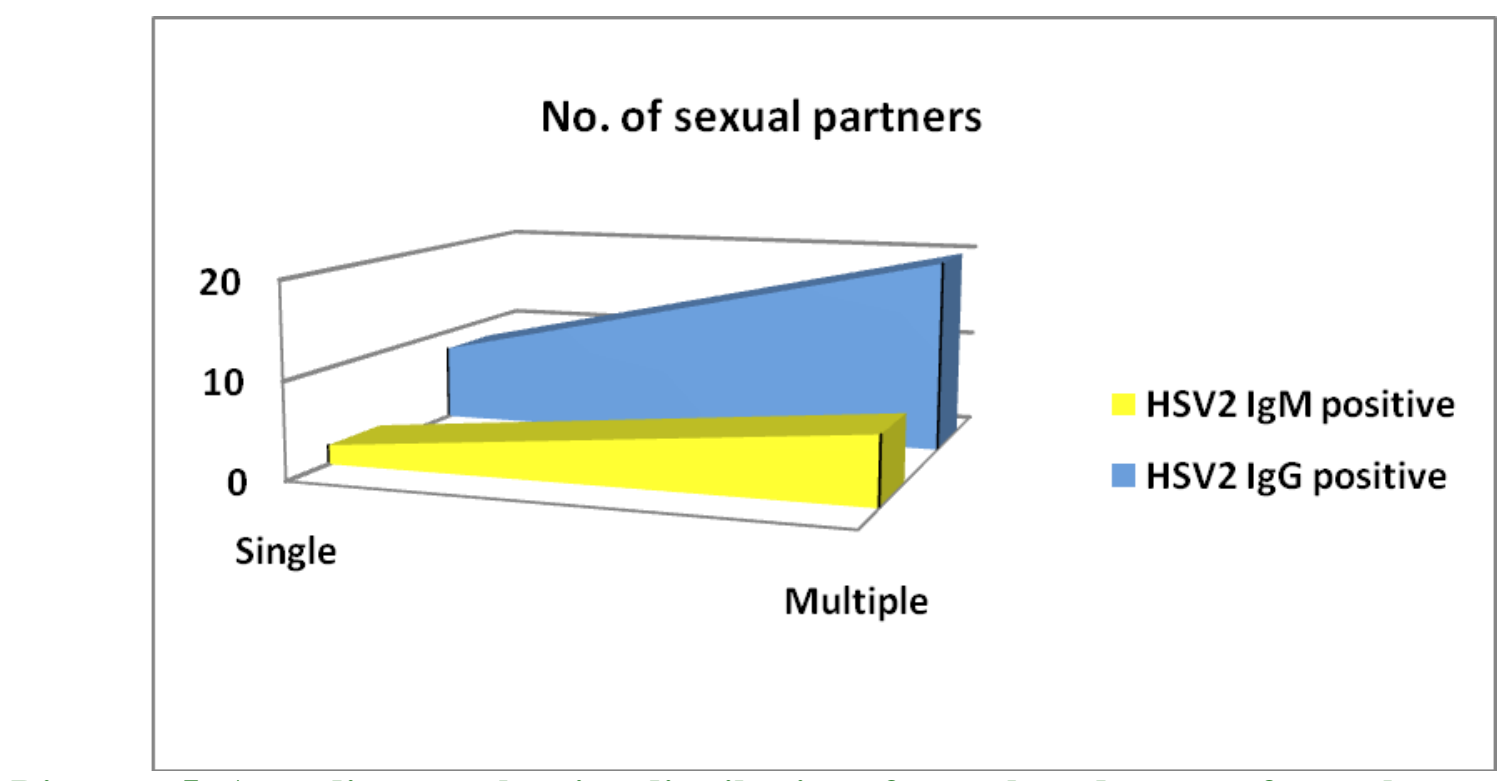

Diagram 5: Area diagram showing distribution of cases based on no. of sexual partners 


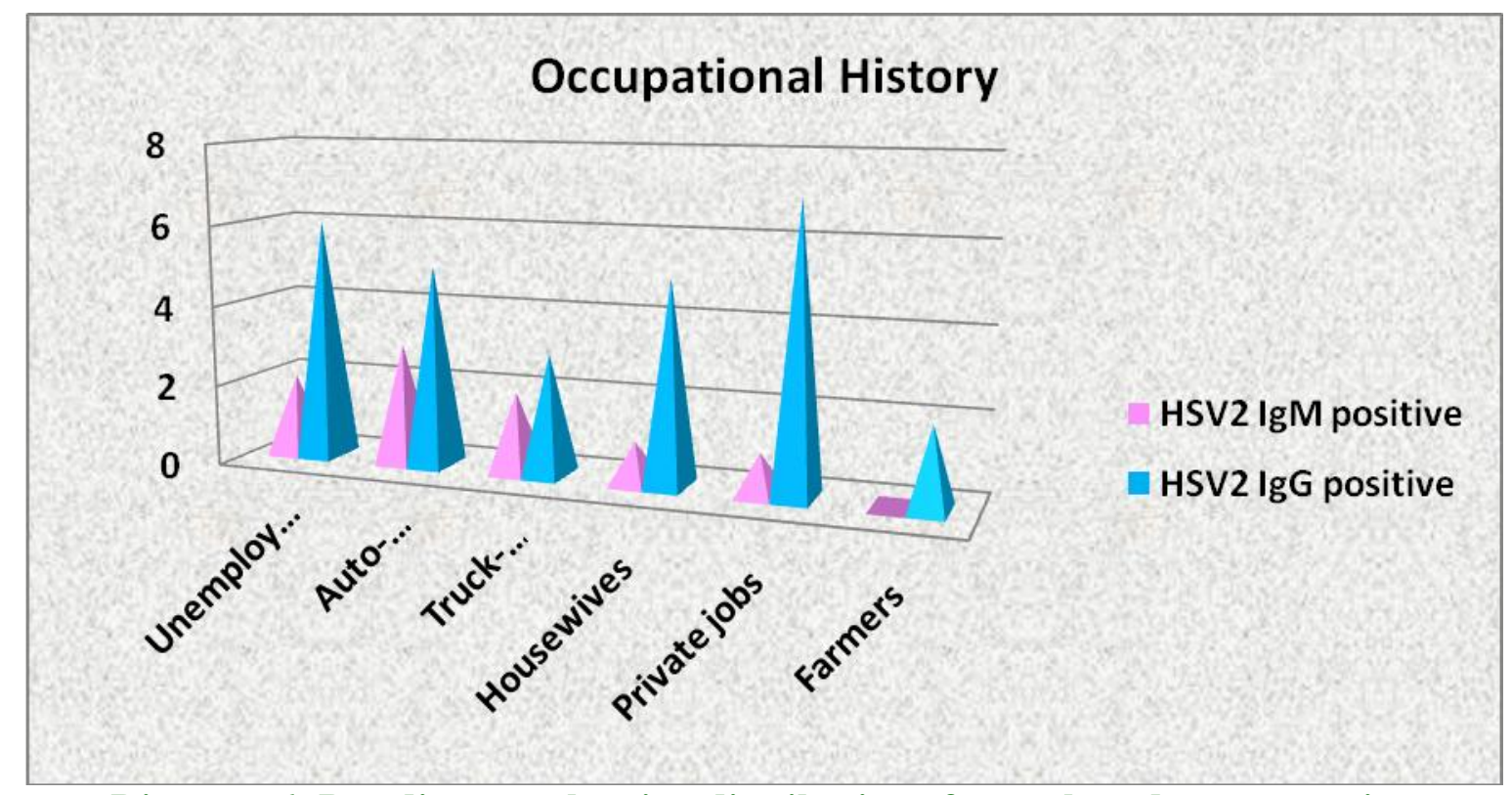

Diagram 6: Bar diagram showing distribution of cases based on occupation

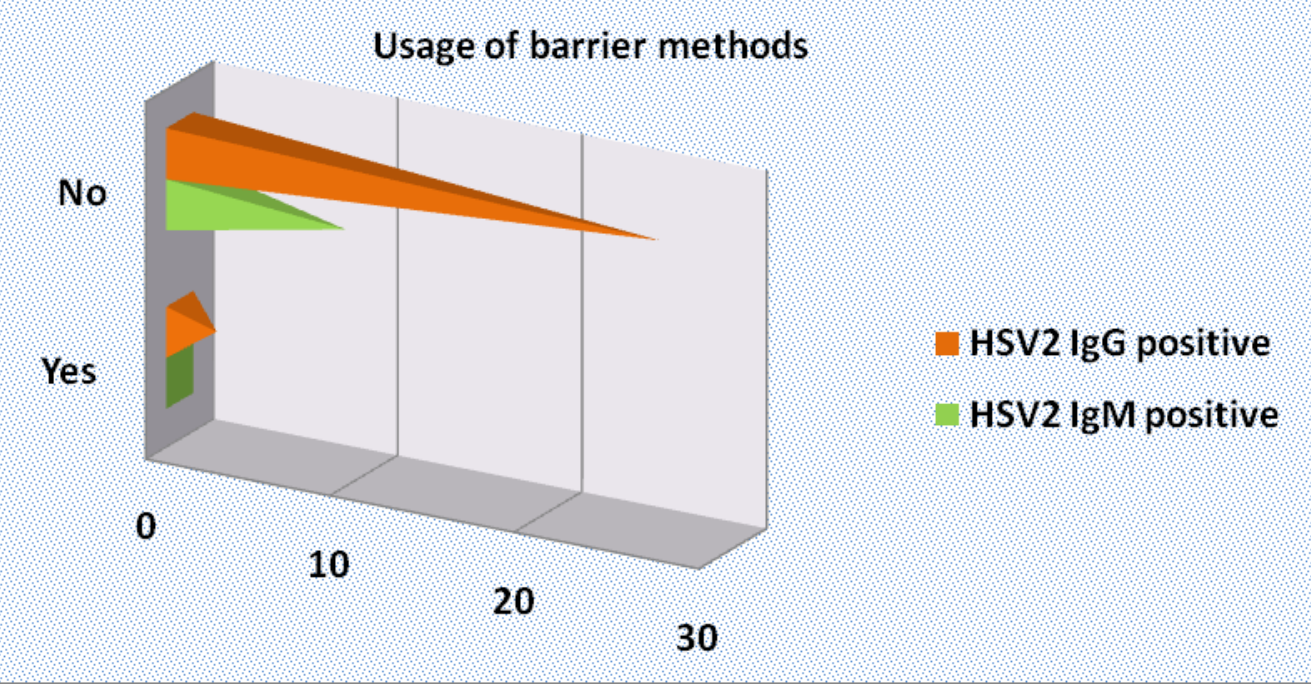

Diagram 7: Bar diagram showing HSV2 seroprevalence in relation to usage of barrier methods

In the study population, only $12 \%$ individuals with antibodies to HSV2 gave history of symptoms suggestive of genital herpes. Similar findings were observed by Bassett et al., (1994); Gottlieb et al., (2002); Janier et al., (1999); Varela et al., (2001) and Wald et al., (2000).

In the present study, the prevalence of antibodies to HSV2 was higher among STD patients with multiple sexual partners (51\%) than that of patients with a single partner (21\%). A similar association was reported by Cowan et al., (1994); Gottleib et al., (2002); Varela et al., (2001); Fleming et al., (1997) and Weiss et al., (2001).

In the present study, the prevalence for antibody to HSV2 was higher in HIV seropositive individuals than that of HIV 
seronegative individuals (69 \% vs. 30\%) with a ratio of 2.3:1.These findings were comparable with those of Steben and Sacks (1997); Bystricka et al., (1998); Bystricka et al., (2000); Gwanzura et al., (1998); Mbopi - Keou et al., (2000); Wutzler et al., (2000); Lindan et al., Russel et al., (2001) and Wald and Link (2002).

In conclusion, majority of the STD patients with antibodies to HSV2 did not have history of genital herpes. This finding drives home the importance of screening in a community as the majority of persons infected with HSV2 infection are symptomfree. And thus represents the major reservoir for HSV2 transmission.

This study emphasizes the importance of studying the disease by serological methods. HSV2 seroprevalence is high among HIV seropositive individuals than among HIV seronegative individuals. Thus HSV2 could be an important risk factor in acquiring HIV infection.

High HSV2 seroprevalence in STD patients and its significant association with HIV infection demonstrates the need for regular HSV2 screening in STD patients. Asymptomatic individuals also can be serologically identified as carrying HSV2 and/or HIV infection.

Proper counseling and effective treatment for HSV/HIV will not only reduce the rate of transmission of HSV2 infection but also decrease the incidence of HIV infection. However, the findings made in the present study were to be confirmed in larger population-based studies so that more definitive conclusions can be made.

\section{References}

Anna Wald, Judith Zeh, Stacy Selke, Rhoda, L., Ashley and Lawrence Corey. 1995.
Virologic characteristics of subclinical and symptomatic genital herpes infections. The New England J. Med., 333(12): 770-775.

Anna Wald, Lawrence Corey, Richard Cone, Ann Hobson, Gray Davis and Judy Zeh. 1997. Frequent Genital Herpes Simplex Virus 2 Shedding in Immunocompetent Women Effect of Acyclovir Treatment. J. Clin. Invest., 99(5): 1092-1097.

Bassett, I., Donovan, B., Field, P.R., et al. 1994. HSV2 infection of heterosexual men attending a sexual health Centre. Med. J. Aust., 160: 697.

Bhushan Kumar, Somesh Gupta. 2005. Sexually transmitted infections, $1^{\text {st }}$ edition, Elsevier publications, 191-214.

Bystricka, M., Gasparovicova, L., StaneKova, D., et al. 2000. Prevalence of antibodies to HSV2 among homosexual men either positive or negative for HIV in Slovakia. Actavirol., 44: 163.

Bystricka, M., Stanekova, D., Mokras, M., et al. 1998. Antibody responses to the HSV2 glycoprotein G in sera of HIV infected patients in Slovakia. Actavirol., 42: 319 .

Cowan, F.M., Johnson, A.M., Ashley, R., Corey, L., Mindel, A. 1994. Antibody to herpes simplex virus type 2 as serological marker of sexual lifestyle in populations. BMJ., 309: 1325 -1329.

David, W., Kimberlin and Dwight, J. 2004. Rouse Genital Herpes. N Engl. J. Med., 350: 1970-77.

Fleming, D.T., McQuillan, G.M., Johnson, R.E., Nahmias, A.J., Aral, S.O., et al. 1997. Herpes simplex virus type 2 in the United States, 1976 to 1994. N Engl. J. Med., 337: 1105 - 11.

Gottleib, S.L., Douglas, J.M., Schmid, S., et al. 2002. Seroprevalence and correlates of herpes simplex virus type 2 infections in 5 STD clinics. J. Infect. Dis., 186 : $1381-1389$.

Gwanzura, L., McFarland, W., Alexander, D,. et al. 1988. Association between HIV and HSV2 seropositivity among male 
factory workers in Zimbabwe. J. Infect. Dis., 177: 481.

Janier, M., lassau, F., Bloch, J., et al. 1999. Seroprevalence of HSV2 antibodies in an STD clinic in Paris. Int. J. STD AIDS, $10: 522$.

Jawetz, Melnick, Adelberg's Medical Microbiology, Twenty-Sixth Edition, McGraw Hill 2013: 467-476.

Lindan, C., Jerajani, H.T., Mathur, M.S., Gogate, A. et al. Men attending public STD clinics in Mumbai have high rates of HIV, exposure to sex workers, male male sex, and herpes simplex 2 infection.

Marc Steben, Stephen, L. 1997. Sacks National goals for the prevention and control of sexually transmitted diseases in Canada. Volume - 23 S6.

Mbopi - Keou, Fx, Gresenguet, G., Mayaud, P., et al. 2000. Interactions between Herpes simplex virus type 2 and human Immunodeficiency virus type 1 infection in African women: Opportunities for Intervention. J. Infect. Dis., 182: 1090 - 6.

Nahmias, A.J., Lee, F.K., Nahmias, S.B. 1990. Seroepidemiological and Sociological patterns of Herpes simplex virus infection in the world. Scand J. Infect. Dis., $69: 19-36$.

Russell, D.B., Tabrizi, S.N., Ressell, J.M., Gorland, S.M. 2001. Seroprevalence of HSV1 and HSV2 in HIV infected and uninfected homosexual men in a primary care setting. J. Clin. Virol., 22: 305.
Sgaier, S.K., P. Mony, S. Jayakumar, C. McLaughlin, P. Arora, R. Kumar, P. Bhatia, P. Jha. 2011. Prevalence and correlates of Herpes Simplex Virus-2 and syphilis infections in the general population in India. Sex Transm. Infect., 87: 94e100.

Santos, L.D.R., Da Silva, A.G., Pereira, A.C. 1996. Herpes simplex virus type 2 in Brazil: Seroepidemiologic survey Int. J. Dermatol., 35: 794 - 796.

Varela, J.A., Corbeira, P.G., Aguanell, M.V., et al. 2001. Herpes simplex virus type 2 seroepidemiology in Spain J. American sexually transmitted diseases association, 28: 47- 50.

Wald, A., Link, K. 2002. Risk of HIV infection in HSV2 seropositive persons: A Meta-analysis, J. Infect. Dis., 185: 45.

Wald, A., Zeh, J., Selke, S., Warren, T., et al. 2000. Reactivation of genital herpes simplex virus type 2 infection in asymptomatic seropositive persons. $N$ Engl. J. Med., 342: 844 - 50.

Weatherall, D.J., Ledingham, J.G.G., Warrell, D.A. 1996. Oxford Textbook of Medicine, 3rd edition, Oxford Medical Publishers.

Weiss, H.A., Buve, A., Robinson, N.J., et al. 2001. The epidemiology of HSV2 infection and its association with HIV infection in 4 urban African populations. AIDS, 15: S 97- S108.

Wutzler, P., Doerr, H.W., Farber, I., et al. 2000. Seroprevalence of HSV1 and HSV2 in selected German populations J. Med. Virol., 61: 201.

\section{How to cite this article:}

Venkata Hemalatha Neeli, Perala Bala Murali Krishna and Medidi Deborah Purushottam. 2016. Seroprevalence of Herpes Simplex Virus2 in Sexually Transmitted Diseases in a Tertiary Care Hospital in Visakhapatnam, India. Int.J.Curr.Microbiol.App.Sci. 5(9): 562-573. doi: http://dx.doi.org/10.20546/ijcmas.2016.509.063 